\title{
Skeletal development of suckling kittens with and without supplementary calcium phosphate
}

\author{
By JEAN E. SLATER AND ELSIE M. WIDDOWSON \\ Medical Research Council Department of Experimental Medicine, \\ University of Cambridge
}

(Received 29 March $196 \mathrm{I}$ )

It is well known that the bones of all newborn mammals are less highly calcified than those of adults of the same species, and it might be expected that during the suckling period the milk, which is usually regarded as a rich source of calcium, would rapidly increase the degree of calcification of the skeleton. This does not, however, appear to happen. Burns \& Henderson (1936b) and Weidmann \& Rogers (1958) have shown that the percentage of $\mathrm{Ca}$ in the dry fat-free cortical bone of kittens decreases during the first week or two after birth and that it is only when the animals are 3 weeks old that the value begins to increase towards the adult level. There is also a fall in the percentage of $\mathrm{Ca}$ in the cancellous bone, and this fall goes on for a much longer time. The course of events is similar in the puppy (Burns \& Henderson, 1936b), in the rabbit (Weidmann \& Rogers, I958), in the rat (Dickerson \& Widdowson, I960) and possibly also in the pig (Dickerson, 1959; Slater, 1960). All these animals grow rapidly; the bones increase considerably in size during the suckling period, but the amount of calcium or of phosphorus available in the mother's milk does not seem to be enough to enable the calcification of the skeleton to keep pace with its increase in size. The human body grows comparatively slowly but Stearns (I939) has suggested, from a consideration of the results of balance studies, that the skeleton of a breast-fed infant may be no more highly calcified at 6 months than it is at birth. Stettner (I93I) used the term 'physiologische Osteoporose' to describe the decrease in density as seen on X-ray examination of the bones of the hands of healthy children between birth and 2 years, and Dickerson $(1959,1962 b)$ has recently obtained direct evidence that there is a fall in the degree of calcification of the human femur during the first 6 months after birth.

All investigators who have measured the intakes and excretions of $\mathrm{Ca}$ and $\mathrm{P}$ by babies receiving cow's-milk preparations have been struck by the large retentions compared with those of babies receiving breast milk (Rominger \& Meyer, 1927; Jeans \& Stearns, 1933; Stearns, I939; Slater, I96r), and this difference has never been fully explained. Appreciation of the general principle, however, that calcification does not keep pace with growth on a diet of mother's milk makes it clear that there is probably room for extra $\mathrm{Ca}$ and $\mathrm{P}$ in the developing bones. It is almost impossible to obtain sufficient post-mortem material from human infants aged 3-6 months and known to have lived only on breast milk or on cow's milk to enable one to say with certainty that the bones of bottle-fed babies are indeed more highly calcified, though circumstantial 
evidence makes it appear certain that it must be so. The problem has therefore been taken to animals. Kittens were chosen, since it was known from previous work that their bones normally show a fall in the proportion of $\mathrm{Ca}$ during the ist week or so of life. They were suckled by their mother, but some were given a supplement of calcium phosphate each day. The effects of this supplement on the total amount of $\mathrm{Ca}$ in the body and on the size and chemical structure of the bones have been examined.

\section{EXPERIMENTAL}

Administration of calcium phosphate. Three litters of kittens, born to a well-nourished cat, were used. There were six animals in each of the first two litters and four in the third. They were weighed as soon as possible after birth, and one from each litter was killed to provide information about the bones at the time of birth. The method of killing and dissection (see below) was the same as for the animals 7 days old. The remainder of the litter was returned to the mother, who continued to suckle them throughout the 7 days of the experiment. Two from each of the first two litters and one from the third were given a supplement of calcium phosphate, the others receiving no supplement. No figures for the concentration of $\mathrm{Ca}$ and $\mathrm{P}$ in cat's milk could be found in the literature, nor could anything be discovered about the quantity of milk normally ingested by kittens. The amount of $\mathrm{Ca}$ and $\mathrm{P}$ to be given as a dietary supplement was therefore fixed on the basis of the composition of the newborn kitten and its known rate of growth. At birth the kitten contains about $0.78 \mathrm{~g} \mathrm{Ca}$ and $0.52 \mathrm{~g} \mathrm{P}$ (Widdowson, 1950). A suspension of calcium phosphate $\left(\mathrm{CaHPO}_{4} \cdot 2 \mathrm{H}_{2} \mathrm{O}\right)$ in distilled water was prepared to contain $53.3 \mathrm{mg} \mathrm{Ca}$ and $41 \cdot 3 \mathrm{mg} \mathrm{P} / \mathrm{ml}$. The suspension was warmed and shaken, and $2 \mathrm{ml}$ were measured as accurately as possible in a $2 \mathrm{ml}$ syringe. This amount was administered by stomach tube each morning and evening for 7 days, so that by the end of the Ist week each kitten had had $\mathrm{I} \cdot 49 \mathrm{~g} \mathrm{Ca}$ and $\mathrm{I} \cdot \mathrm{I} 6 \mathrm{~g} \mathrm{P}$. The last dose was given $\mathrm{I} 4 \mathrm{~h}$ before the animals were killed. The supplement caused no ill effects. The mother cat was not disturbed by the handling of her kittens, and there was no sign of diarrhoea.

Killing and dissection of the animals and preparation of the material for analysis. On the morning of the 8 th day after birth the animals that had received calcium phosphate, and litter-mates that had not, were weighed and then given $50 \mathrm{mg}$ pentobarbitone sodium BP intraperitoneally. Blood $(5-6 \mathrm{ml})$ was collected by heart puncture, and the serum was separated. Any urine in the bladder was removed with a syringe and needle and then stored under toluene. The whole gut was removed, the stomach was emptied, and the contents were analysed; a sample of milk regurgitated by one of the control kittens that had received no supplement was also analysed.

The left femur and humerus and the parietal bones were dissected out, scraped free of all muscle and tendon and weighed in a closed container. The long bones were measured and dissected as described by Dickerson \& Widdowson (I960).

The carcasses of the animals, including the soft tissues removed in cleaning the bones, but excluding the digestive tract, were weighed in tared trays and dried at $100^{\circ}$ to constant weight. They were then repeatedly extracted with light petroleum 
(b.p. $40-60^{\circ}$ ) at room temperature, the residual light petroleum was removed first at room temperature and then at $100^{\circ}$, and the defatted carcasses were again weighed and then ground in a mechanical mill to a fine powder, which was sampled for further analysis.

The bones were also dried at $100^{\circ}$ to constant weight, and the fat was extracted from the femur and humerus with light petroleum at room temperature, as described for the whole carcass. The skull bones were not defatted. The dry matter was ground to a fine powder with a pestle and mortar, and the powder was sampled for analysis.

The stomach contents and regurgitated milk were sampled for analysis by weight, the serum and urine by volume.

Chemical methods. Small portions of dried carcass were used for the determination of total $\mathrm{N}$. They were digested with $\mathrm{H}_{2} \mathrm{SO}_{4}$, with copper selenite as catalyst, and the ammonia was determined by micro-Kjeldahl distillation. Other samples were weighed into silica crucibles and ashed in a muffle furnace at $450^{\circ}$. Portions of urine, stomach contents and regurgitated milk were also measured into silica crucibles, dried and then ashed in a similar way. The ash was extracted with $\mathrm{HCl}$, as described by McCance, Widdowson \& Shackleton (1936), and determinations of $\mathrm{Ca}$ and $\mathrm{P}$ were made on the acid extract of the ash by the methods used by Economou-Mavrou $\&$ McCance (1958). The powdered samples of bone were heated with $6 \mathrm{~N}-\mathrm{HCl}$ in sealed tubes in a boiling water-bath for $48 \mathrm{~h}$, and the resulting solution was used for the determination of $\mathrm{N}$, collagen, $\mathrm{Ca}$ and $\mathrm{P}$, as described by Dickerson \& Widdowson (1960). It was assumed that the collagen of kittens contains $13.5 \%$ hydroxyproline and that collagen contains $18 \% \mathrm{~N}$.

Determinations of $\mathrm{Ca}$ and $\mathrm{P}$ were made directly on the serum as described by Economou-Mavrou \& McCance (1958).

\section{RESULTS}

Growth in weight. The animals in both groups approximately doubled their birth weights during the week of observation (Table I). The experimental kittens did not gain as much weight on the average as those receiving no supplement; the reason probably was that the administration of $4 \mathrm{ml}$ of fluid by stomach tube each day prevented the kittens taking as much milk as their litter-mates. The conclusions are unlikely to be vitiated by this small difference in growth rate.

Table 1. Body-weights of newborn kittens and of suckling kittens after I week with or without a supplement of $\mathrm{CaHPO}_{4}$

\begin{tabular}{|c|c|c|c|c|}
\hline \multicolumn{5}{|c|}{ (Mean values and ranges) } \\
\hline Kittens & $\begin{array}{l}\text { No. of } \\
\text { animals }\end{array}$ & $\begin{array}{l}\text { Weight at } \\
\text { birth (g) }\end{array}$ & $\begin{array}{l}\text { Weight at } \\
\text { I week }(g)\end{array}$ & $\begin{array}{c}\text { Gain in } \\
\text { weight (g) }\end{array}$ \\
\hline Newborn & 3 & $\begin{array}{c}115 \\
(100-126)\end{array}$ & - & 一 \\
\hline Without supplement & 5 & $\begin{array}{c}\mathrm{I} 2 \mathrm{I} \\
(\mathrm{I} 14-\mathrm{I} 28)\end{array}$ & $\begin{array}{c}252 \\
(236-259)\end{array}$ & $\begin{array}{c}\text { r } 3 \mathbf{r} \\
(122-137)\end{array}$ \\
\hline With supplement & 5 & $\begin{array}{c}125 \\
\left(\begin{array}{ll}1 & 15-133\end{array}\right)\end{array}$ & $\begin{array}{c}237 \\
(2 \mathrm{I}-269)\end{array}$ & $\begin{array}{c}112 \\
(96-136)\end{array}$ \\
\hline
\end{tabular}


Table 2. Concentrations of calcium and phosphorus in regurgitated milk and in stomach. contents of five suckling kittens with or without a supplement of $\mathrm{CaHPO}_{4}$

\begin{tabular}{|c|c|c|c|}
\hline & $\mathrm{Ca}$ & $\mathbf{P}$ & Ratio, Ca:P \\
\hline Regurgitated milk (mg/roo g) & $34^{\circ} 6$ & $70 \cdot 3$ & $0 \cdot 49$ \\
\hline $\begin{array}{l}\text { Stomach contents* }(\mathrm{mg} / \mathrm{r} 00 \mathrm{~g}) \text { : } \\
\text { Without supplement }\end{array}$ & $\begin{array}{c}68 \cdot 2 \\
\left(55^{\circ}-75 \cdot 5\right)\end{array}$ & $\begin{array}{c}142 \\
(108-169)\end{array}$ & $\begin{array}{c}0.48 \\
(0.44-0.51)\end{array}$ \\
\hline With supplement & $\begin{array}{c}625 \\
(572-7 \circ 8)\end{array}$ & $\begin{array}{c}444 \\
(4+2-489)\end{array}$ & $\begin{array}{c}1 \cdot 4 I \\
(I \cdot 35-I \cdot 45)\end{array}$ \\
\hline $\begin{array}{l}\text { Suspension of calcium phosphate } \\
\text { administered }(\mathrm{mg} / 100 \mathrm{ml})\end{array}$ & $533^{\circ}$ & $413^{\circ}$ & I.29 \\
\hline
\end{tabular}

* Mean values and ranges.

Composition of the stomach contents and of regurgitated milk. The stomach contents of the control group of kittens contained twice as high a concentration of $\mathrm{Ca}$ and $\mathrm{P}$ as the sample of regurgitated milk, but the $\mathrm{Ca}: \mathrm{P}$ ratio was the same (Table 2). The $\mathrm{Ca}: \mathrm{P}$ ratio of cat's milk is evidently considerably lower than those of human milk $(\mathrm{r} \cdot 6)$, sow's milk $\left(\mathrm{I}^{\cdot} 5\right)$ and cow's milk $(\mathrm{r} \cdot 3)$, which is reflected in the urinary excretion of $P$ (see below).

There was much more $\mathrm{Ca}$ and $\mathbf{P}$ in the stomach contents of the experimental kittens. Although the last dose of calcium phosphate was given $14 \mathrm{~h}$ before the animals were killed, and they undoubtedly fed during the interval, the $\mathrm{Ca}: \mathrm{P}$ ratio of their stomach contents was higher than it was in the calcium phosphate administered.

Composition of the serum. The concentrations of $\mathrm{Ca}$ and $\mathrm{P}$ in the serum were higher in the supplemented group, the mean values with standard deviations $(\mathrm{mg} / 100 \mathrm{ml})$ being:

$\begin{array}{lcc} & \mathrm{Ca} & \mathrm{P} \\ \text { Without supplement } & 9 \cdot 32 \pm 0.280 & 9 \cdot 37 \pm 0.302 \\ \text { With supplement } & 9 \cdot 87 \pm 0.298 & 9 \cdot 75 \pm 0.245\end{array}$

There was no overlap in the ranges, but the differences were not statistically significant.

Composition of the urine. The urinary excretion of $\mathrm{P}$ by suckling kittens $(25.6 \mathrm{mg} /$ I00 $\mathrm{ml}$, SD 5.57) was much higher than that of $\mathrm{Ca}(2.27 \mathrm{mg} / \mathrm{I} 00 \mathrm{ml}, \mathrm{SD} \mathrm{0.24})$. This is the reverse of the findings for the breast-fed human infant (Slater, $196 \mathrm{I}$ ) and the suckling piglet (Widdowson, 196r) and is no doubt due to the high $\mathrm{P}:$ Ca ratio of cat's milk. The kittens that received extra calcium phosphate had a higher concentration of $P$ in their urine $(66.8 \mathrm{mg} / 100 \mathrm{ml}$, sD $8 \cdot 53)$, but a lower concentration of $\mathrm{Ca}(\mathrm{r} \cdot 60 \mathrm{mg} /$ $100 \mathrm{ml}$, sD 0.66 ).

Composition of the bodies. Table 3 sets out the amounts of $\mathrm{Ca}$ and $\mathrm{P}$ in the whole bodies of the kittens at birth and at I week of age, first per Ioo $g$ fresh, fat-free body tissue and secondly as total quantities in the body. The 'body' includes the various bones that were taken for separate analysis, but it excludes the whole of the digestive tract, for it was removed from all the animals.

The total amounts of $\mathrm{Ca}$ and $\mathrm{P}$ in the whole bodies of kittens not receiving a supplement were $60 \%$ higher at the end of $\mathrm{I}$ week than at birth. The amounts retained from the milk were not sufficient, however, to maintain the concentration of $\mathrm{Ca}$ and $\mathrm{P}$ in 
Table 3. Calcium and phosphorus concentrations ( $\mathrm{g} / \mathrm{100} \mathrm{g}$ fresh fat-free body tissue) and total amounts $(g)$ in bodies of three newborn kittens and five suckling kittens after I week with or without a supplement of $\mathrm{CaHPO}_{4}$

\begin{tabular}{|c|c|c|c|c|}
\hline \multirow[b]{2}{*}{ Kittens } & \multicolumn{2}{|c|}{ Concentration* } & \multicolumn{2}{|c|}{ Total amount } \\
\hline & $\mathrm{Ca}$ & $\mathbf{P}$ & $\mathrm{Ca}$ & $\mathbf{P}$ \\
\hline Newborn & $\begin{array}{c}0.73 \\
(0.71=0.78)\end{array}$ & $\begin{array}{c}0.50 \\
(0.46-0.55)\end{array}$ & 0.73 & 0.50 \\
\hline Without supplement & $\begin{array}{c}0.65 \\
(0.60-0.67)\end{array}$ & $\begin{array}{c}0.45 \\
(0.42-0.46)\end{array}$ & $I \cdot I 8$ & 0.82 \\
\hline With supplement & $\begin{array}{c}0.73 \\
(0.68-0.77)\end{array}$ & $\begin{array}{c}0.50 \\
(0.49-0.53)\end{array}$ & $I \cdot 33$ & 0.91 \\
\hline
\end{tabular}

the fat-free body tissue at the newborn level, for the fat-free body tissue had itself increased in weight by $100 \%$ during the same time. The total amounts of $\mathrm{Ca}$ and $\mathrm{P}$ in the bodies of the kittens receiving the supplement were greater than in the control animals, although the body-weights were lower. Each of these kittens received $\mathrm{I} \cdot 49 \mathrm{~g} \mathrm{Ca}$ and $\mathrm{I} \cdot \mathrm{I} 6 \mathrm{gP}$ during the week of experiment so that the percentage of the dose retained appeared to be $\mathrm{IO}$ and 8 for $\mathrm{Ca}$ and $\mathrm{P}$, respectively. If the experimental animals had weighed as much as the controls at the end of the week they would probably have retained a little more of the supplement. The extra retention was enough to prevent a fall in the concentration of $\mathrm{Ca}$ and $\mathrm{P}$ in the fat-free body tissue, but not sufficient to promote a rise.

Table 4. Measurements of fresh femur and humerus of three newborn kittens and five suckling kittens after $\mathrm{I}$ week with or without a supplement of $\mathrm{CaHPO}_{4}$

(Mean values and ranges)

\begin{tabular}{|c|c|c|c|c|c|}
\hline Kittens & $\begin{array}{l}\text { Weight } \\
\text { (mg) }\end{array}$ & $\begin{array}{l}\text { Width } \\
\text { (mm) }\end{array}$ & $\begin{array}{l}\text { Length } \\
(\mathrm{mm})\end{array}$ & $\begin{array}{c}\text { Ratio, } \\
\text { width:length }\end{array}$ & $\begin{array}{c}\text { Thickness } \\
\text { of shaft } \\
\text { (mm) }\end{array}$ \\
\hline \multicolumn{6}{|c|}{ Femur } \\
\hline Newborn & $\begin{array}{c}329 \\
(315-355)\end{array}$ & $\begin{array}{c}2 \cdot 5 \\
(2 \cdot 4-2 \cdot 5)\end{array}$ & $\begin{array}{c}25 \cdot 4 \\
(24 \cdot 5-26 \cdot 4)\end{array}$ & $\begin{array}{c}0.098 \\
(0.095-0.102)\end{array}$ & $\begin{array}{c}0.5 \\
(\text { all } 0.5)\end{array}$ \\
\hline Without supplement & $\begin{array}{c}595 \\
\left(568-63^{8}\right)\end{array}$ & $\begin{array}{c}3.0 \\
(2 \cdot 9-3 \cdot 0)\end{array}$ & $\begin{array}{c}30 \cdot 7 \\
(30 \cdot I-3 I \cdot 4)\end{array}$ & $\begin{array}{c}0.097 \\
(0.093-0.099)\end{array}$ & $\begin{array}{c}0.7 \\
(0.6-0.8)\end{array}$ \\
\hline With supplement & $\begin{array}{c}5^{86} \\
(426-73 I)\end{array}$ & $\begin{array}{c}3 \cdot 0 \\
(2 \cdot 7-3 \cdot 2)\end{array}$ & $\begin{array}{c}30 \cdot I \\
\left(28 \cdot 1-3 r^{\circ} \cdot 0\right)\end{array}$ & $\begin{array}{c}0.100 \\
(0.096-0.104)\end{array}$ & $\begin{array}{c}0.8 \\
(0.6-1 \cdot 0)\end{array}$ \\
\hline \multicolumn{6}{|c|}{ Humerus } \\
\hline Newborn & $\begin{array}{c}392 \\
\left(35^{2}-448\right)\end{array}$ & $\begin{array}{c}2 \cdot 4 \\
(2 \cdot 3-2 \cdot 5)\end{array}$ & $\begin{array}{c}25 \cdot 8 \\
(25 \cdot 4-26 \cdot 2)\end{array}$ & $\begin{array}{c}0.093 \\
(0.092-0.096)\end{array}$ & $\begin{array}{c}0.7 \\
(0.6-0.7)\end{array}$ \\
\hline Without supplement & $\begin{array}{c}655 \\
(588-698)\end{array}$ & $\begin{array}{c}2 \cdot 7 \\
(2 \cdot 6-2 \cdot 8)\end{array}$ & $\begin{array}{c}30 \cdot 6 \\
(30 \cdot 0-3 I \cdot 6)\end{array}$ & $\begin{array}{c}0.088 \\
(0.084-0.093)\end{array}$ & $\begin{array}{c}0.7 \\
(0.6-0.8)\end{array}$ \\
\hline With supplement & $\begin{array}{c}660 \\
\left(498-76_{5}\right)\end{array}$ & $\begin{array}{c}2 \cdot 9 \\
(2 \cdot 7-3 \cdot 1)\end{array}$ & $\begin{array}{c}30 \cdot 1 \\
(28 \cdot 0-31 \cdot 0)\end{array}$ & $\begin{array}{c}0.096 \\
(0.91-0.100)\end{array}$ & $\begin{array}{c}0.9 \\
(0.6-I \cdot r)\end{array}$ \\
\hline
\end{tabular}

Measurements of the long bones. Both femur and humerus were slightly shorter in length in the kittens receiving the supplement (Table 4); this difference was probably 
related to the smaller body size. In spite of it, the mean width of the bones was the same or greater, so that the width: length ratio was higher in the bones of the experimental animals. There appeared to be a fall in this ratio during the ist week of life in the humerus of animals being suckled normally; the additional calcium phosphate converted the fall into a rise. The thickness of the shaft was also slightly greater in the experimental animals, suggesting that the additional calcium phosphate promoted formation of periosteal bone. It may also have decreased resorption of bone from the medullary surface.

Composition of the bones. Table 5 sets out the compositions of the dry fat-free femur and humerus (excluding the epiphyses) of the three groups of kittens. There was a small rise in the percentage of total and collagen $\mathrm{N}$ and a fall in the percentage of $\mathrm{Ca}$ and $\mathrm{P}$ in the bones of the kittens suckled normally during the ist week after birth and therefore a fall in the $\mathrm{Ca}: \mathrm{N}$ ratio. In the kittens receiving the additional calcium phosphate the amounts of $\mathrm{Ca}$ and $\mathrm{P}$ deposited were almost sufficient to prevent any fall in the percentage of these elements in the rapidly growing bones, but they were not enough to promote a rise.

Table 5. Composition of femur and humerus (excluding epiphyses) of three newborn kittens and five suckling kittens after I week with or without a supplement of $\mathrm{CaHPO}_{4}$

( $g / 100 \mathrm{~g}$ dry fat-free bone; mean values and ranges)

\begin{tabular}{|c|c|c|c|c|c|}
\hline \multirow{3}{*}{ Kittens } & \multicolumn{4}{|c|}{ (g/100 g dry fat-free bone; mean values and ranges) } & \multirow{3}{*}{$\begin{array}{l}\text { Ratio, } \\
\mathrm{Ca}: \mathrm{N}\end{array}$} \\
\hline & Total N & Collagen $\mathrm{N}$ & $\mathrm{Ca}$ & $\mathbf{P}$ & \\
\hline & & Femur & & & \\
\hline Newborn & $\begin{array}{c}5 \cdot I \\
(4 \cdot 8-5 \cdot 4)\end{array}$ & $\begin{array}{c}2 \cdot 8 \\
(2 \cdot 6-3 \cdot 0)\end{array}$ & $\begin{array}{c}22 \cdot 7 \\
(21 \cdot 8-23 \cdot 6)\end{array}$ & $\begin{array}{c}10.4 \\
(10 \cdot 2-10.6)\end{array}$ & $\begin{array}{c}4^{*} 5 \\
\left(4^{\cdot 1}-4^{-9}\right)\end{array}$ \\
\hline Without supplement & $\begin{array}{c}5 \cdot 9 \\
(5 \cdot 5-6 \cdot 9)\end{array}$ & $\begin{array}{c}3 \cdot 1 \\
(2 \cdot 9-3 \cdot 2)\end{array}$ & $\begin{array}{c}21 \cdot 3 \\
(19 \cdot 8-22 \cdot 1)\end{array}$ & $\begin{array}{c}10.1 \\
(9.3-10.4)\end{array}$ & $\begin{array}{c}3.7 \\
(3 \cdot 2-4 \cdot 0)\end{array}$ \\
\hline \multirow[t]{2}{*}{ With supplement } & $\begin{array}{c}5^{\cdot 6} \\
\left(5^{\cdot} 4^{-5} \cdot 8\right)\end{array}$ & $\begin{array}{c}3 \cdot 0 \\
(2 \cdot 9-3 \cdot 2)\end{array}$ & $\begin{array}{c}22 \cdot 4 \\
(21 \cdot 5-23 \cdot 8)\end{array}$ & $\begin{array}{c}10.2 \\
(10.1-10.3)\end{array}$ & $\begin{array}{c}4 \cdot 0 \\
(3 \cdot 8-4 \cdot 2)\end{array}$ \\
\hline & & Humerus & & & \\
\hline Newborn & $\begin{array}{c}5 \cdot 1 \\
(4 \cdot 9-5 \cdot 4)\end{array}$ & $\begin{array}{c}3 \cdot 0 \\
\text { (all } 3 \cdot 0)\end{array}$ & $\begin{array}{c}23 \cdot 6 \\
(22 \cdot 5-24 \cdot 5)\end{array}$ & $\begin{array}{c}10.7 \\
(10.6-10.8)\end{array}$ & $\begin{array}{c}4 \cdot 7 \\
(4 \cdot 2-5 \cdot 1)\end{array}$ \\
\hline Without supplement & $\begin{array}{c}5 \cdot 5 \\
(4 \cdot 8-6 \cdot 0)\end{array}$ & $\begin{array}{c}3 \cdot 1 \\
(3 \cdot 0-3 \cdot 2)\end{array}$ & $\begin{array}{c}22 \cdot 1 \\
(21 \cdot I-22 \cdot 7)\end{array}$ & $\begin{array}{c}10 \cdot 3 \\
(9 \cdot 7-10 \cdot 8)\end{array}$ & $\begin{array}{c}4^{\cdot 0} \\
(3 \cdot 8-4 \cdot 4)\end{array}$ \\
\hline With supplement & $\begin{array}{c}5 \cdot 1 \\
(4 \cdot 8-5 \cdot 5)\end{array}$ & $\begin{array}{c}3 \cdot 1 \\
(2 \cdot 8-3 \cdot 2)\end{array}$ & $\begin{array}{c}23.5 \\
(2 \times \cdot 9-25 \cdot 0)\end{array}$ & $\begin{array}{c}1 \mathrm{I} \cdot \mathrm{I} \\
(10 \cdot 8-\mathrm{II} \cdot 5)\end{array}$ & $\begin{array}{c}4 \cdot 7 \\
(4 \cdot 3-5 \cdot 2)\end{array}$ \\
\hline
\end{tabular}

Burns \& Henderson (1936b) and Weidmann \& Rogers (1958) analysed separately the central part of the shaft, representing cortical bone, and the metaphysial trabeculae, representing cancellous bone. In our investigation no attempt was made to separate the metaphyses exactly, but cortical bone from the centre of the shaft was analysed, and its composition is set out in Table 6 . The cortex of the humerus was more highly calcified than that of the femur at the time of birth, and a higher proportion of its $\mathrm{N}$ was contributed by collagen. There was no significant change in the composition of cortical bone of either the femur or the humerus during the ist week after birth, and the composition of the bone was unaffected by the supplement of calcium phosphate. All the changes shown in Table 5 must therefore have been due to changes in the degree of calcification of the metaphyses. Burns \& Henderson (1936b) 
Table 6. Composition of cortical bone of femur and humerus of three newborn kittens and five suckling kittens after $\mathrm{I}$ week with or without a supplement of $\mathrm{CaHPO}_{4}$

( $\mathrm{g} / 100 \mathrm{~g}$ dry fat-free bone; mean values and ranges)

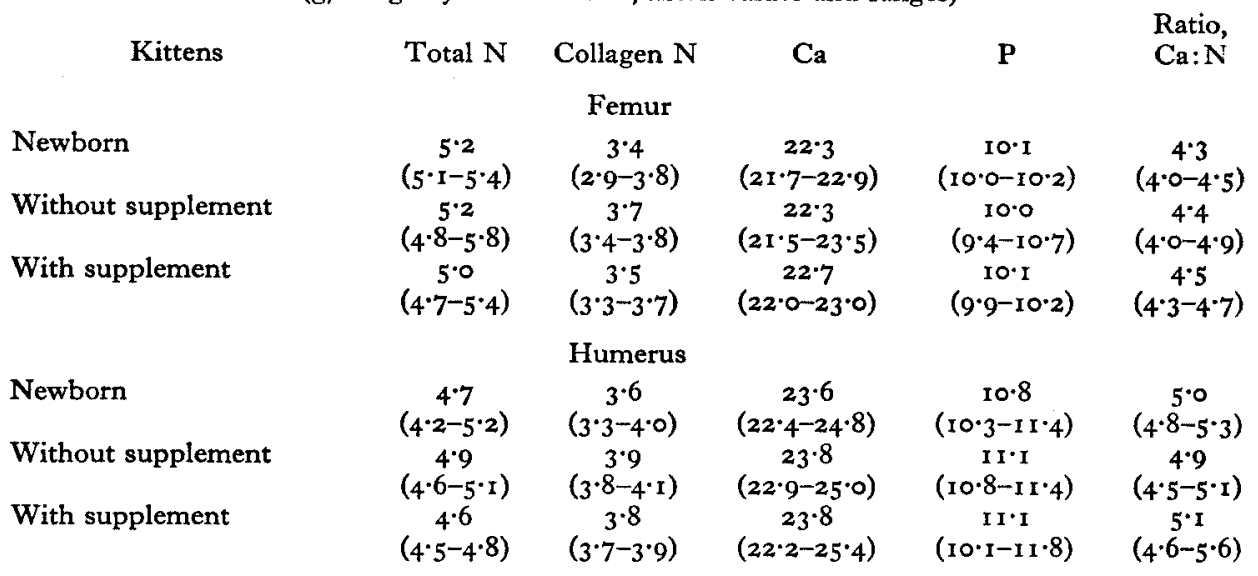

and Weidmann \& Rogers (1958) observed a greater fall in calcification of cancellous than of cortical bone, but they did observe a small change in the latter. Why our results should be different from theirs is not clear, unless it had something to do with the state of nutrition of the mother cat and her ability to lactate. Our kittens were certainly heavier than those studied by Weidmann \& Rogers; their average weight at birth was higher than these authors' maximum, and the weight at 7 days was also considerably higher.

Table 7 shows the composition of the dried epiphyses. There was an increase in ossification of the epiphyses during the Ist week, and it was not significantly affected by the supplement of calcium phosphate.

Table 7. Composition of epiphyses of femur and humerus of three newborn kittens and five suckling kittens after $\mathrm{I}$ week with or without a supplement of $\mathrm{CaHPO}_{4}$

(g/roo g dry epiphyses; mean values and ranges)

\begin{tabular}{|c|c|c|c|c|}
\hline Kittens & Total N & Collagen N & $\mathrm{Ca}$ & $\mathbf{P}$ \\
\hline \multicolumn{5}{|c|}{ Femur } \\
\hline Newborn & $\begin{array}{c}x 1 \cdot 2 \\
(10 \cdot 7-1 \pm \cdot 6)\end{array}$ & $\begin{array}{c}5.9 \\
(5 \cdot 5-6.4)\end{array}$ & $\begin{array}{c}0.99 \\
(0.98-1 \cdot 00)\end{array}$ & $\begin{array}{c}0.79 \\
(0.78-0.80)\end{array}$ \\
\hline Without supplement & $\begin{array}{c}I I \cdot 2 \\
(I I \cdot I-I I \cdot 4)\end{array}$ & $\begin{array}{c}6 \cdot 1 \\
(6 \cdot 0-6 \cdot 2)\end{array}$ & $\begin{array}{c}\mathrm{r} \cdot 57 \\
(\mathrm{x} \cdot 4-\mathrm{I} \cdot 9)\end{array}$ & $\begin{array}{c}0.97 \\
(0.85-1.03)\end{array}$ \\
\hline With supplement & $\begin{array}{c}11 \cdot 3 \\
(10 \cdot 8-12 \cdot 0)\end{array}$ & $\begin{array}{c}6 \cdot 1 \\
(5 \cdot 7-6 \cdot 5)\end{array}$ & $\begin{array}{c}I \cdot 73 \\
(r \cdot 5-2 \cdot 0)\end{array}$ & $\begin{array}{c}I \cdot 02 \\
(0.94-1 \cdot 08)\end{array}$ \\
\hline \multicolumn{5}{|c|}{ Humerus } \\
\hline Newborn & $\begin{array}{c}10 \cdot 9 \\
(10 \cdot 7-11 \cdot I)\end{array}$ & $\begin{array}{c}5^{\cdot 9} \\
\left(5^{\circ} 8-5 \cdot 9\right)\end{array}$ & $\begin{array}{c}0.97 \\
(0.93-\mathrm{I} \cdot 0 \mathrm{I})\end{array}$ & $\begin{array}{c}0.74 \\
(0.62-0.86)\end{array}$ \\
\hline Without supplement & $\begin{array}{c}11 \cdot 2 \\
(I 1 \cdot 0-11 \cdot 4)\end{array}$ & $\begin{array}{c}6.4 \\
(5.9-6.6)\end{array}$ & $\begin{array}{c}1 \cdot 35 \\
(I \cdot 2-1 \cdot 5)\end{array}$ & $\begin{array}{c}0.97 \\
(0.94-0.99)\end{array}$ \\
\hline With supplement & $\begin{array}{c}11 \cdot 0 \\
(10 \cdot 0-11 \cdot 5)\end{array}$ & $\begin{array}{c}6 \cdot 5 \\
(6 \cdot 2-7 \cdot 0)\end{array}$ & $\begin{array}{c}I \cdot 43 \\
(I \cdot 2-I \cdot 7)\end{array}$ & $\begin{array}{c}0.98 \\
(0.92-I \cdot I r)\end{array}$ \\
\hline
\end{tabular}


Burns \& Henderson (1936a) noted that the weight of the epiphyses of the long bones of kittens increased as a percentage of the total weight of the bone during the first 7 days after birth, and the weights of the separated parts of the femur and humerus in our experiments confirmed this observation. Thus, $40 \%$ of the humerus of the newborn kitten was accounted for by the epiphyses and $49 \%$ of the humerus of the kitten $\mathrm{I}$ week old. Both bony tissue and epiphyses increased considerably in size over this period, but the epiphyses increased more in proportion.

Table 8 gives the composition of the parietal bones. Here the fall in the percentage of $\mathrm{Ca}$ in kittens suckled normally, and the partial prevention of this fall when additional calcium phosphate was given, were more striking than in any part of the long bones. The differences in the Ca: $\mathrm{N}$ ratio were significant, and there was no overlap in the ranges.

Table 8. Composition of parietal bones of three nezborn kittens and five suckling kittens after $\mathrm{I}$ week with or without a supplement of $\mathrm{CaHPO}_{4}$

\begin{tabular}{|c|c|c|c|c|c|}
\hline Kittens & Total N & Collagen $\mathrm{N}$ & $\mathrm{Ca}$ & $\mathbf{P}$ & $\begin{array}{l}\text { Ratio, } \\
\text { Ca:N }\end{array}$ \\
\hline Newborn & $\begin{array}{c}5 \cdot 4 \\
(5 \cdot 3-5 \cdot 5)\end{array}$ & $\begin{array}{c}4^{\cdot 1} \\
\left(3^{*} 9^{-}-4^{\cdot 2}\right)\end{array}$ & $\begin{array}{c}25 \cdot 9 \\
(25 \cdot 4-26 \cdot 3)\end{array}$ & $\begin{array}{c}10 \cdot 8 \\
(10 \cdot 4-11 \cdot 2)\end{array}$ & $\begin{array}{c}4 \cdot 8 \\
(4 \cdot 7-5 \cdot 0)\end{array}$ \\
\hline Without supplement & $\begin{array}{c}5 \cdot 5 \\
(5 \cdot 4-5 \cdot 8)\end{array}$ & $\begin{array}{c}4 \cdot 3 \\
(4 \cdot 0-4 \cdot 6)\end{array}$ & $\begin{array}{c}21 \cdot 6 \\
(19 \cdot 9-23 \cdot 0)\end{array}$ & $\begin{array}{c}10 \cdot 3 \\
\left(9^{\circ} \cdot 4^{-1} I^{\circ} \circ\right)\end{array}$ & $\begin{array}{c}3 \cdot 9 \\
(3 \cdot 7-4 \cdot 1)\end{array}$ \\
\hline With supplement & $\begin{array}{c}5 \cdot 3 \\
(5 \cdot 1-5 \cdot 4)\end{array}$ & $\begin{array}{c}4 \cdot 2 \\
(3 \cdot 8-4 \cdot 6)\end{array}$ & $\begin{array}{c}22 \cdot 9 \\
(22 \cdot 1-23 \cdot 7)\end{array}$ & $\begin{array}{c}10 \cdot 7 \\
(10 \cdot 1-11 \cdot 2)\end{array}$ & $\begin{array}{c}4 \cdot 4 \\
(4 \cdot 1-4 \cdot 7)\end{array}$ \\
\hline
\end{tabular}

\section{DISCUSSION}

The fall in the percentage of water in bones during growth is accompanied by a rise in the proportions of organic and inorganic material. The maturation of bone tissue is generally associated with a greater increase in the percentage of $\mathrm{Ca}$ and $\mathrm{P}$ than of $\mathrm{N}$ and by an increase up to almost $100 \%$ in the proportion of the total $\mathrm{N}$ contributed by collagen (Dickerson, I $962 b$ ). It is clear from the present results that the bone tissue of the newborn kitten is far from mature in the last-mentioned respect.

Our results for kittens confirm those of others in demonstrating a fall in the percentage of $\mathrm{Ca}$ in the dry fat-free bone tissue of the femur and humerus and a fall in the $\mathrm{Ca}: \mathrm{N}$ ratio during the rst week of life. They further show that the same occurs in the parietal bones of the skull. It therefore appears that on a diet of mother's milk there may be a hold-up, or even a reversal, of the progress of calcification. Similar changes have been found in the femur of human babies in the 6 months after birth (Dickerson, $1962 b$ ) and in the pig's humerus during the latter half of gestation (Dickerson, 1962a), and it must be concluded that at certain times in the development of these three species the deposition of bone mineral does not keep pace with the production of new bone matrix.

Bauer, Aub \& Albright (1929) stained bone sections from newly born kittens with alizarin red and demonstrated that there was during growth a reorganization in the trabecular bone of the metaphysis. At birth the metaphysis was filled with trabeculae, which rapidly disappeared during the first weeks of life, and Bauer et al. suggested, 
as did Burns \& Henderson ( $1936 b$ ) after them, that the trabeculae may form a 'reserve' to be drawn upon during subsequent growth. It looks as though cancellous bone does not provide the only 'reserve', and the degree of calcification of cortical bone seems to be maintained at the expense of membrane bone as well as of cancellous bone.

The results for the bones of the kittens given supplementary calcium phosphate show that the degree of calcification of cancellous and membrane bone could be maintained by increasing the amount of $\mathrm{Ca}$ and $\mathrm{P}$ in the diet, but the dietary supplement made no difference to the composition of the cortical bone. These observations on individual bones and parts of bones are confirmed by the results for the whole body, for the amounts of $\mathrm{Ca}$ and $\mathrm{P}$ absorbed and retained from the supplement were sufficient to prevent any fall in the concentration of $\mathrm{Ca}$ and $\mathrm{P}$ in the fresh fat-free body tissue, but they did not, on the other hand, lead to any increase in concentration of these constituents over and above the values at birth.

\section{SUMMARY}

I. Suckling kittens were given a supplement of $\mathrm{CaHPO}_{4}$ by stomach tube twice a day for the first 7 days after birth, and the size and composition of their bodies and bones were compared with those of litter-mates suckled in the same way, but without any supplement, and with others killed directly after birth.

2. All the suckled animals approximately doubled their birth weights during the week of study. There was a decrease in concentration of $\mathrm{Ca}$ in the fat-free body tissue of the animals suckled normally; the amounts of $\mathrm{Ca}$ and $\mathrm{P}$ retained from the supplement were sufficient to prevent this fall, but not to promote a rise.

3. There was a decrease in concentrations of $\mathrm{Ca}$ in the dry parietal bones and in the dry fat-free long bones of the kittens suckled normally and a fall in the $\mathrm{Ca}: \mathrm{N}$ ratios. In the long bones, however, the decrease was confined to the cancellous bone of the metaphyses.

4. When the supplement of calcium phosphate was given, the decrease in the degree of calcification was prevented, but in no bone or part of bone was there an increase in percentage of $\mathrm{Ca}$ or in the $\mathrm{Ca}: \mathrm{N}$ ratio.

We are most grateful to Dr J. W. T. Dickerson for his help at every stage of this investigation and to Professor R. A. McCance for his constructive criticisms of our manuscript. One of us (J.E.S.) thanks Joseph Rank, Ltd, for a studentship which made this work possible.

\section{REFERENCES}

Bauer, W., Aub, J. C. \& Albright, F. (1929). F. exp. Med. 49, 145.

Burns, C. M. \& Henderson, N. (1936a). Biochem. F. 30, 1202.

Burns, C. M. \& Henderson, N. (1936b). Biochem. F. 30, 1207.

Dickerson, J. W. T. (1959). The effects of development on the composition of the organs and tissues. Ph.D. Thesis, University of Cambridge.

Dickerson, J. W. T. (1962a). Biochem. F. 82, 47.

Dickerson, J. W. T. (1962b). Biochem. F. 82, 56 .

Dickerson, J. W. T. \& Widdowson, E. M. (1960). Proc. roy. Soc. B, 152, 207.

Economou-Maviou, C. \& McCance, R. A. (1958). Biochem. F. 68, 573 .

Jeans, P. C. \& Stearns, G. (1933). Amer. F. Dis. Child. 46, 49. 
McCance, R. A., Widdowson, E. M. \& Shackleton, L. R. B. (1936). Spec. Rep. Ser. med. Res. Coun., Lond., no. 213 .

Rominger, E. \& Meyer, H. (1927). Arch. Kinderheilk. 80, 195.

Slater, J. E. (1960). Retentions of dietary constituents during the neonatal period. Ph.D. Thesis, University of Cambridge.

Slater, J. E. (196I). Brit. F. Nutr. r5, 83.

Stearns, G. (1939). Physiol. Rev. I9, 415.

Stettner, E. (1931). Z. Kinderheilk. 52, 1.

Weidmann, S. M. \& Rogers, H. J. (1958). Biochem. F. 69, 338.

Widdowson, E. M. (1950). Nature, Lond., 166, 626.

Widdowson, E. M. (196I). In Somatic Stability in the Newly Born, p. 39. Ciba Found. Symp. London: J. and A. Churchill. 